\title{
穿刺吸引細胞診を用いた乳癌および転移性肝癌に対する 癌化学療法効果判定の試み
}

\author{
鳥取大学医学部第 1 外科 \\ 広岡 保明 浜副 隆一 塩田 摂成 大谷 真二 \\ 小林 誠人 貝原 信明
}

穿刺吸引細胞診を用いて乳癌および転移性肝癌の治療効果判定を試み, その有用性を検討した。 動注化学療法あるいは局所温熱療法併用下に動注化学療法が施行された乳癌 3 例, 転移性肝癌 14 例（大腸癌：10 例, 胃癌：4 例）を対象として, 穿刺吸引細胞診の手技を用いて癌細胞を採取 し，治療前後における癌細胞の変性度（degeneration index：DI）と腫瘍縮小率より判定した奏効 度および患者生存期間とを対比検討した。

治療後の癌細胞には，核の腫大・膨化，巨細胞・多核巨細胞化，核クロマチンの粗造化など，核 の変化が主に認められた。治療後の DI の変化と奏効度とはよく一致し, DI の変化が +5 点以上の 症例は全例 partial response（PR）群であった。 大腸癌肝転移症例の治療後の DI の変化と治療後 生存期間との間には有意 $(\mathrm{P}<0.001)$ な相関関係を認めた.

以上より, 乳癌抢よび転移性肝癌における治療後の DI の変化は, 局所治療効果の判定ならびに 予後予測因子として有用であることが示唆され，穿刺吸引細胞診を用いた本法は治療効果判定法と して有効であると考えられた。

Key words : Breast cancer-Metastatic liver cancer-Aspiration cytology—-Therapeutic effect

\section{I.はじめに}

本邦に打ける癌化学療法の治療効果判定法として は, 日本癌治療学会の固形がん化学療法直接効果判定 基準 ${ }^{1)}$ (以下，日癌治判定基準と略す）が現在広く一

Cytological evaluation of chemotherapeutic effects on breast cancer and metastatic liver cancer

Yasuaki HIROOKA, M.D., Ryuichi HAMAZOE, M.D., Setsujyo SHIOTA, M.D., Shinji OHTANI, M.D., Makoto KOBAYASHI, M.D., Nobuaki KAIBARA, M.D.

First Department of Surgery, Faculty of Medicine, Tottori University

論文別刷請求先 $\quad 683$ 鳥取県米子市西町 36 鳥取大学医学 部第 1 外科広岡保明

平成 6 年 10 月 3 日受付

平成 7 年 4 月 28 日受理
般に用いられている。海外においてはWHOの評価 法少があるが，いくつかの問題点があるため, Moertel $ら^{3)}$ により治療効果判定の誤差をなくすための検 討が行われており，わが国のような基準作成が好まし いと指摘されている4).このように日癌治判定基準は 国際的にも通用し，他施設の成績と比較でき，誰にで も，どの施設でも判定が可能である ${ }^{5)}$ とう合理的な 判定基準であるが，実際の臨床で応用した場合，腫瘍 の体積が算出できる例では面積より体積で治療効果を 判定したほうが誤差が少ない3), 組織学的判定基準が なく腫瘍の内部構造の変化（中心壊死など）が奏効度 に反映されない，あるいは奏効度が予後を完全には反 映していない5)など, 種々の問題点が指摘されてい る.われわれはこれらの問題点を解決し, 臨床で応用 しやすい治療効果判定法を確立するため, 乳癌および 
転移性肝癌に対して治療前後における腫瘍内部の変化 を細胞レベルで捉えた治療効果判定を試み，その有用 性につき検討したので報告する。

\section{II. 対象および方法}

\section{1. 対象}

表 1 に示すごとく，体表病巣としては局所温熱療法 併用内胸動脈内化学療法（以下，内胸動注と略す）が 施行された原発性乳癌 3 例を対象とした。体深部病巣 としては転移性肝癌 14 例（原発巣：大腸癌 10 例, 胃 癌 4 例）を対象とした。転移性肝癌は全例肝両葉に多 数散在性に転移を認める $\mathrm{H} \mathrm{3}^{6,7)}$ 症例で, 原発巣の大 部分は高分化型の腺癌であった。転移性肝癌 14 例中 8 例に肝動脈内化学療法（以下, 肝動注と略す）が施 行され，6例に局所温熱療法併用肝動注が施行され た。乳癌病巣は治療後に姑息的に切除され，大腸癌お
よび胃癌原発巣は化学療法開始前に姑息的切除がなさ れた。内胸動注には adriamycin (ADM) $10 \mathrm{mg}$ およ び 5-fluorouracil（5-FU） $250 \mathrm{mg}$ を用いて毎週 1 回 の局所温熱療法施行時に動注し，原則として 2 カ月間 治療した。肝動注には cis-platinum (CDDP) 25〜30 $\mathrm{mg}$ および 5-FU $250 \mathrm{mg}$ を用いて毎週 1 回動注し, 原則として 2 力月間治療した。局所温熱療法併用肝動 注症例は上記肝動注時に局所温熱療法を併用した。局 所温熱療法には radiofrequency（RF）誘電加温装置 (Thermotron RF-8：山本ビニター社製）を用いた。

癌細胞は, 治療前抢よび治療開始 2 力月後にそれぞ れの病巣より穿刺吸引細胞にて採取された。すなわ ち, 乳癌病巣においては腫瘍辺縁の表層より約 $5 \mathrm{~mm}$ の部位より穿刺吸引し，肝転移巣においてはエコー上 腫瘍中心部を避けて, 腫瘍辺縁部よりエコーガイド下 に PTC 針（22 ゲージ）を用いて穿刺吸引した。

表 1 対象症例

\begin{tabular}{|c|c|c|c|c|c|c|c|c|c|c|c|c|}
\hline \multirow{2}{*}{ No. } & \multirow{2}{*}{ 年齢 } & \multirow{2}{*}{$\begin{array}{c}\text { 病巣 } \\
\text { (原発巣) }\end{array}$} & \multirow{2}{*}{$\begin{array}{l}\text { 原発巣の } \\
\text { 組織型 }\end{array}$} & \multirow{2}{*}{$\begin{array}{l}\text { 肝転移 } \\
\text { 度 }\end{array}$} & \multirow{2}{*}{ 化学療法 } & \multirow{2}{*}{ 抗癌剂 } & \multirow{2}{*}{$\begin{array}{c}\text { 治療後 } \\
\text { 中心壊死 }\end{array}$} & \multirow{2}{*}{$\begin{array}{l}\text { 奏効 } \\
\text { 度 }\end{array}$} & \multicolumn{3}{|c|}{ 細胞変性度 } & \multirow{2}{*}{$\begin{array}{l}\text { 治療後生存 } \\
\text { 期間 (月) }\end{array}$} \\
\hline & & & & & & & & & 治療前 & 治療後 & 変化 & \\
\hline 1 & 47 & $\begin{array}{l}\text { 転移性肝癌 } \\
\text { (大腸癌) }\end{array}$ & 高分化腺癌 & H3 & 動注 & $\mathrm{CDDP}+5 \mathrm{FU}$ & - & PR & 0 & 8 & +8 & 32 \\
\hline 2 & 64 & $\begin{array}{l}\text { 転移性肝癌 } \\
\text { (大腸癌) }\end{array}$ & 高分化腺癌 & H3 & 動注 & $\mathrm{CDDP}+5 \mathrm{FU}$ & - & $\mathrm{PR}$ & 1 & 7 & +6 & 20 \\
\hline 3 & 53 & $\begin{array}{l}\text { 転移性肝癌 } \\
\text { (大腸癌) }\end{array}$ & 高分化腺癌 & $\mathrm{H} 3$ & 動注 & $\mathrm{CDDP}+5 \mathrm{FU}$ & + & $\mathrm{NC}$ & 0 & 4 & +4 & 22 \\
\hline 4 & 70 & $\begin{array}{l}\text { 転移性肝癌 } \\
\text { (大腸癌) }\end{array}$ & 高分化腺癌 & $\mathrm{H} 3$ & 動注 & $\mathrm{CDDP}+5 \mathrm{FU}$ & - & $\mathrm{NC}$ & 1 & 2 & +1 & 9 \\
\hline 5 & 58 & $\begin{array}{l}\text { 転移性肝癌 } \\
\text { (大腸癌) }\end{array}$ & 高分化腺癌 & H3 & 動注 & $\mathrm{CDDP}+5 \mathrm{FU}$ & - & PD & 6 & 7 & +1 & 9 \\
\hline 6 & 49 & $\begin{array}{l}\text { 転移性肝癌 } \\
\text { (鱼癌) }\end{array}$ & $\begin{array}{l}\text { 中分化型 } \\
\text { 管状腺癌 }\end{array}$ & H3 & 動注 & $\mathrm{CDDP}+5 \mathrm{FU}$ & - & PR & 1 & 6 & +5 & 16 \\
\hline 7 & 70 & $\begin{array}{l}\text { 転移性肝癌 } \\
\text { (鱼癌) }\end{array}$ & $\begin{array}{l}\text { 中分化型 } \\
\text { 管状腺癌 }\end{array}$ & H3 & 動注 & $\mathrm{CDDP}+5 \mathrm{FU}$ & - & $\mathrm{NC}$ & 1 & 1 & 0 & 3 \\
\hline 8 & 71 & $\begin{array}{l}\text { 転移性肝癌 } \\
\text { (胃癌) }\end{array}$ & 乳頭腺癌 & H3 & 動注 & $\mathrm{CDDP}+5 \mathrm{FU}$ & - & $\mathrm{PD}$ & 2 & 2 & 0 & 5 \\
\hline 9 & 61 & $\begin{array}{l}\text { 転移性肝癌 } \\
\text { (大腸癌) }\end{array}$ & 高分化腺癌 & H3 & 動注 $+R F$ & $\mathrm{CDDP}+5 \mathrm{FU}$ & - & $\mathrm{NC}$ & 2 & 4 & +2 & 7 \\
\hline 10 & 75 & $\begin{array}{l}\text { 転移性肝癌 } \\
\text { (大腸癌) }\end{array}$ & 中分化腺癌 & H3 & 動注 $+R F$ & $\mathrm{CDDP}+5 \mathrm{FU}$ & + & $\mathrm{NC}$ & 4 & 7 & +3 & 12 \\
\hline 11 & 76 & $\begin{array}{l}\text { 転移性肝癌 } \\
\text { (大腸癌) }\end{array}$ & 中分化腺癌 & H3 & 動注 + RF & $\mathrm{CDDP}+5 \mathrm{FU}$ & + & $\mathrm{NC}$ & 2 & 5 & +3 & 18 \\
\hline 12 & 60 & $\begin{array}{l}\text { 転移性肝癌 } \\
\text { (大腸癌) }\end{array}$ & 高分化腺癌 & $\mathrm{H} 3$ & 動注 + RF & $\mathrm{CDDP}+5 \mathrm{FU}$ & - & $\mathrm{NC}$ & 7 & 8 & +1 & 14 \\
\hline 13 & 58 & $\begin{array}{l}\text { 転移性肝癌 } \\
\text { (大腸癌) }\end{array}$ & 高分化腺癌 & H3 & 動注 $+R F$ & $\mathrm{CDDP}+5 \mathrm{FU}$ & - & $\mathrm{NC}$ & 8 & 8 & 0 & 4 \\
\hline 14 & 78 & $\begin{array}{l}\text { 転移性肝癌 } \\
\text { (骨癌) }\end{array}$ & 乳頭腺癌 & H3 & 動注 $+R F$ & $\mathrm{CDDP}+5 \mathrm{FU}$ & - & $\mathrm{NC}$ & 2 & 2 & 0 & 9 \\
\hline 15 & 57 & 乳癌 & 乳頭腺管癌 & Ho & 動注 + RF & $\mathrm{ADM}+5 \mathrm{FU}$ & & PR & 1 & 8 & +7 & 28 \\
\hline 16 & 79 & 乳癌 & 充実腺管癌 & $\mathrm{H} 0$ & 動注+RF & $\mathrm{ADM}+5 \mathrm{FU}$ & & $\mathrm{NC}$ & 4 & 6 & +2 & 17 \\
\hline 17 & 44 & 乳癌 & 乳頭腺管癌 & $\mathrm{H} 0$ & 動注 + RF & $\mathrm{ADM}+5 \mathrm{FU}$ & & $\mathrm{NC}$ & 2 & 5 & +3 & 16 \\
\hline
\end{tabular}

$\mathrm{H} 0$ : 肝転移を認めない, H3 : 肝両葉に多数散在性に転移を認める, 動注：動脈内化学療法, RF : 局所温熱療法, CDDP : cis-platinum, 5FU : 5-fluorouracil, ADM : adriamycin, PR : partial response, NC : no change, PD : progressive disease 
表 2 細胞変性度 (DI) 採点基準

\begin{tabular}{ccccccc}
\hline \hline & $\begin{array}{c}\text { クラスター } \\
\text { 形成能低下 }\end{array}$ & $\begin{array}{c}\text { 染色性 } \\
\text { 低下 }\end{array}$ & $\begin{array}{c}\text { 胞体変化 } \\
\text { (空胞, 裸核) }\end{array}$ & $\begin{array}{c}\text { 核の変化 } \\
\text { (空胞, 粗造) }\end{array}$ & $\begin{array}{c}\text { 多核巨細胞 } \\
\text { 巨細胞化 }\end{array}$ & $\begin{array}{c}\text { 癌細胞数に対する } \\
\text { 塙死物質量增加 }\end{array}$ \\
\hline 不 変 & 0 & 0 & 0 & 0 & 0 & 0 \\
軽 度 & 1 & 1 & 1 & 1 & 1 & 1 \\
中等度 & 2 & 2 & 2 & 2 & 2 & 2 \\
高 度 & 3 & 3 & 3 & 3 & 3 & 3 \\
\hline
\end{tabular}
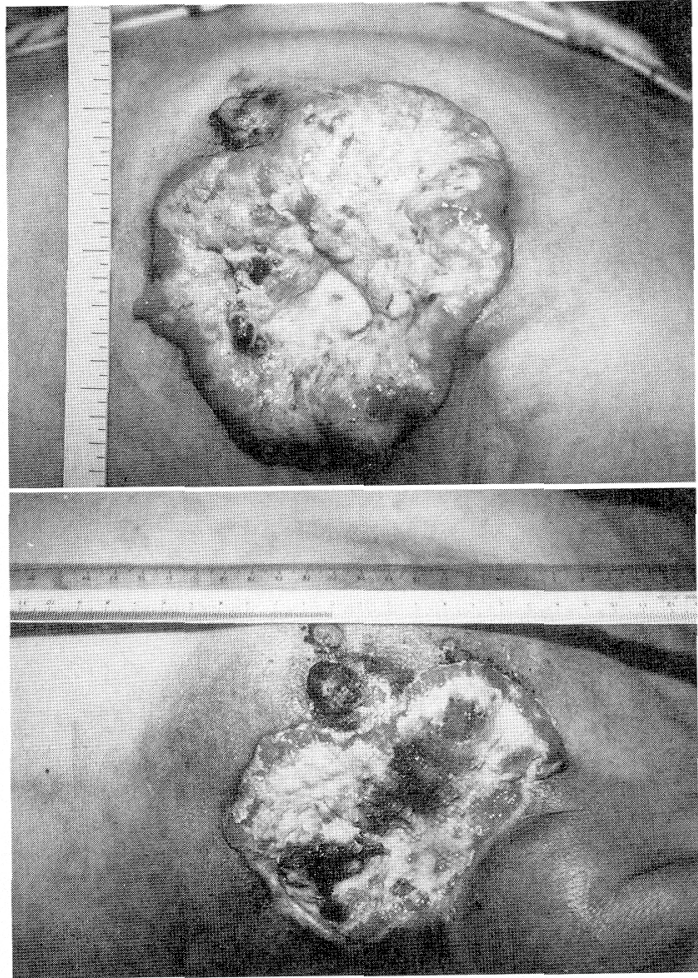

写真 1 原発性乳癌症例。上：治療前，下：治療後に約 $50 \%$ の腫瘍縮小が得られた

\section{2. 細胞変性度 (degeneration index：DI）の算} 定

細胞変性度 (以下，DI と略す） は，穿刺吸引細胞 診で得られた癌細胞約 200 個を検鏡（Papanicolaou 染色，対物 40 倍）し，変性のない腺癌細胞に対する 形態上の変化を表 2 のごとく (1) クラスター形成能の 低下，(2) 染色性の低下，(3) 胞体の変化（空胞，裸核 など)，(4) 核の変化（空胞，クロマチンの凝集や粗造 など)，(5)多核巨細胞・巨細胞化，(6) 癌細胞数に対す る壊死物質量の増加，の6 項目に分類し，それぞれの 変化の程度を変化なし（０点）－変化高度（3点）と し，合計した点数で表わした。

治療前後におけるDIの変化は，治療後の癌細胞の

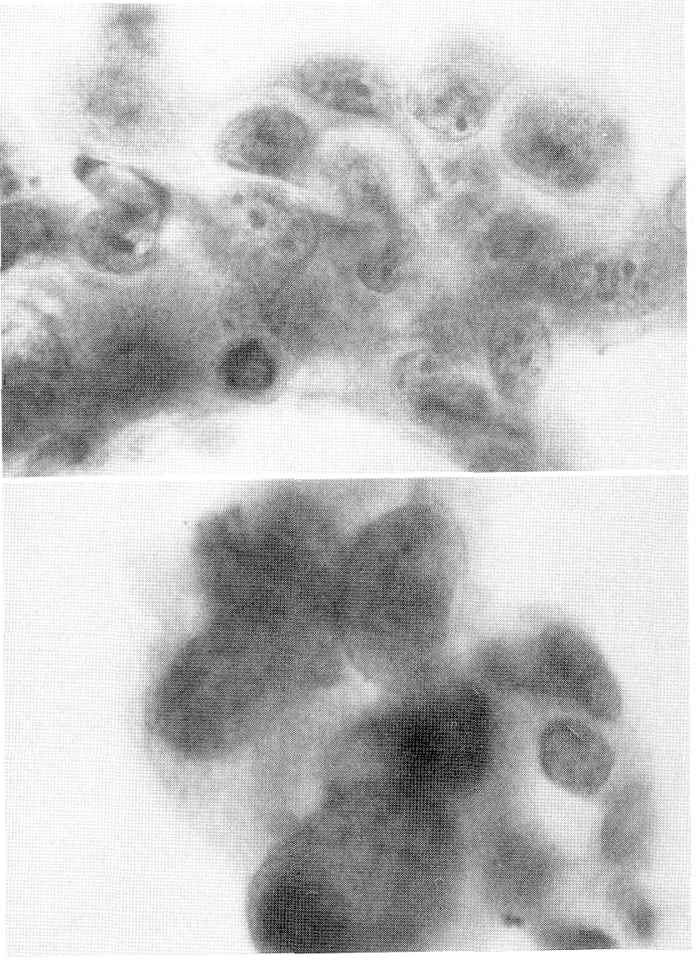

写真 2 原発性乳癌症例厄おける治療前後の穿刺吸引細胞 像。上：治療前, 下：治療後には巨細胞・多核巨細 胞化した変性の強い癌細胞を認める(Pap. 染色X 400)

DI より治療前の癌細胞の DI を引いた点数で示した。

\section{3. 腫瘍縮小率の算定}

乳癌病巣に対する腫瘍縮小率は，治療前後に打ける 触診上の腫瘍の長径と短径を計測して算出した。肝転 移巣に対する腫瘍縮小率は治療前後に打けるCT上最 大の肝転移巣の長径とそれに直角に交わる最大径を計 測して算出した。治療による奏効度は，日癌治判定基 準 ${ }^{1)}$ に従い腫瘍縮小率より CR，PR， NC，PDの 4 群 に分類した。

\section{4. 検討方法}

治療前後における DI の変化と奏効度とを対比検討 した。また，大腸癌肝転移 10 例に抢ける治療前後の 
DI の変化と治療後生存期間とを対比検討した。

III. 結果

\section{1. 治療前後における細胞像の変化}

治療後に腫瘍が触診上約 $50.2 \%$ 縮小し，奏効度 PR と判定された原発性乳癌症例を写真 1 に示した。 写真 2 に治療前後の細胞像を示したが，治療後著明な 巨細胞・多核巨細胞化が扔こり，治療前後における DI の変化は+7点であった。

治療後に中心壊死に陥った大腸癌肝転移症例の CT 像を写真 3 亿示した。本症例に扔いては, 中心壊死に 宿ったにもかかわらず腫瘍自体の大きさの変化がほと んどないため，奏効度 $\mathrm{NC}$ と判定されたが，細胞の 変化は写真 4 に示したごとく，治療後には壊死物質の 増加，核クロマチンの粗造化などの変化を生じ，治療 前後におけるDIの変化は+3点であった。つまり, CT上は変化なしと判定されたものが，細胞診上は変 化ありと判定された。

全症例注打治療後の細胞像の変化としては，核 の腫大・膨化，核》ロマチンの粗造化，巨細胞・多核 巨細胞化など，核の変化が主に認められた。

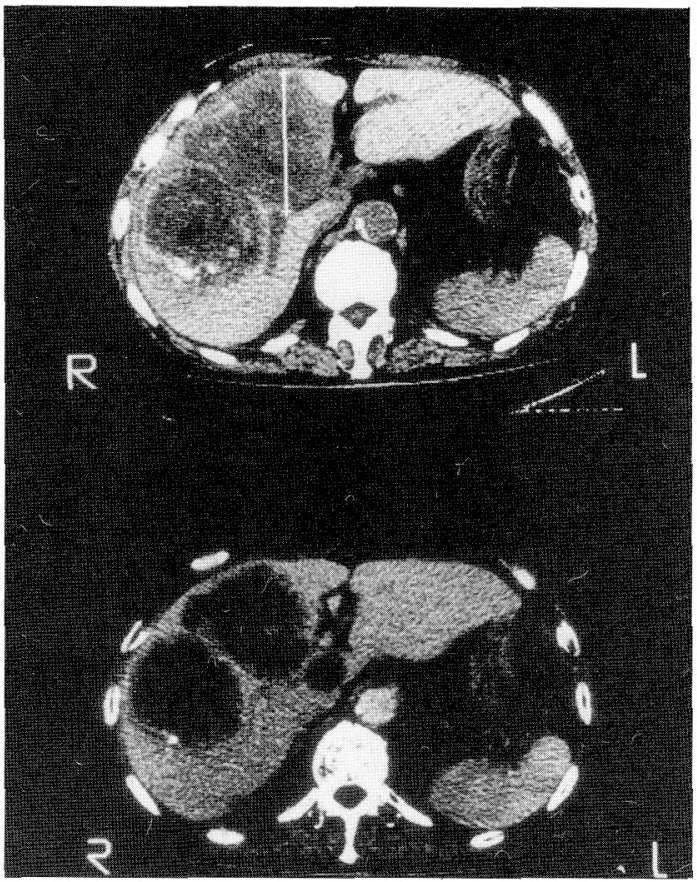

写真 3 転移性肝癌の CT 像。上：治療前，下：治療後に 広範な中心壊死を認めた

\section{2. 治療前後における DI の変化と奏効度}

乳癌における治療前後のDI の変化を図 1 亿示し た。治療前後の DI の変化は, NC 群では+3 点以下 であったが PR 群では+7点と大きかった。

肝動注が施行された転移性肝癌における治療前後の

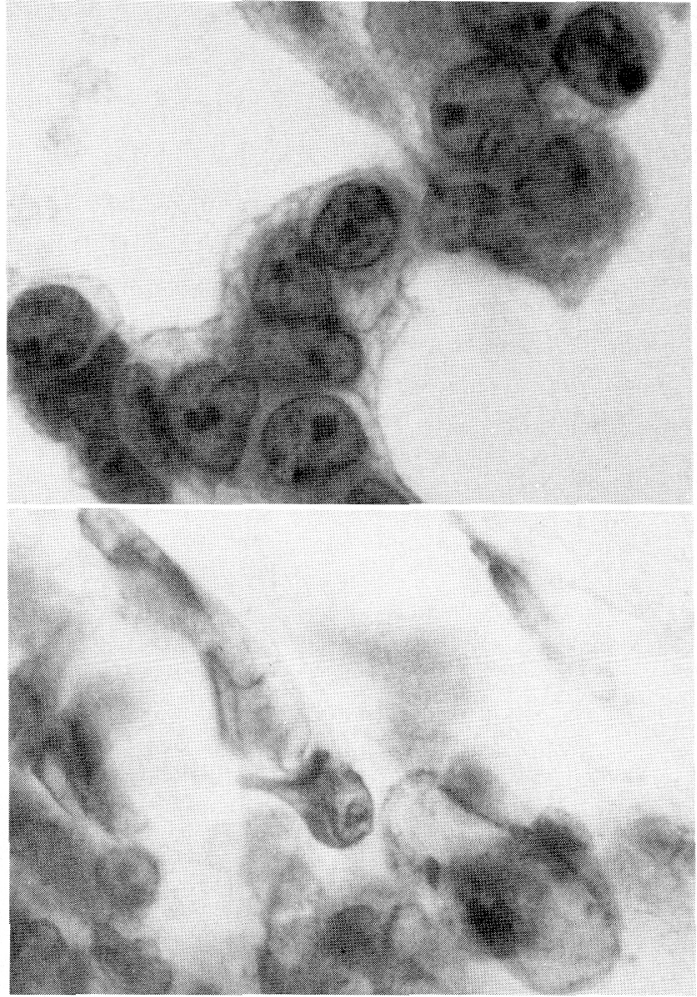

写真 4 転移性肝癌に抢ける治療前後の穿刺吸引細胞像。 上：治療前には viabilityの高い癌細胞を認める, 下：治療後には核の膨化，クロマチンの粗造化，染 色性の低下した癌細胞を認める（Pap. 染色 $\times 400 ）$
PR 群

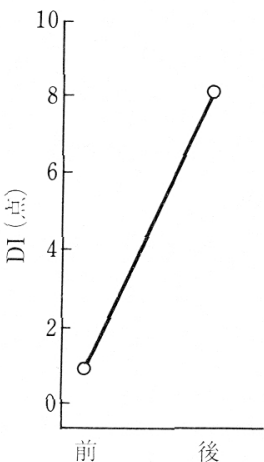

NC 群

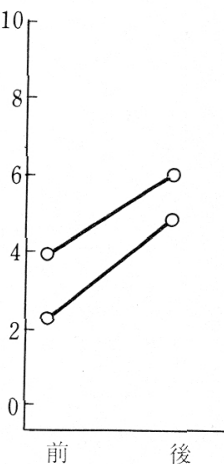

図 1 乳癌に抢ける治療前後の DI の変化 
DI の変化を図 2 に示した. PR 群の治療前後におけ る DI の変化はいずれも +5 点以上であるのに対して, $\mathrm{NC}$ 群, PD 群はすべて +4 点以下で奏効度が悪化す るにつれ DI の変化は小さくなった。また， NC群の 中で, 治療後に CT 上中心壊死を認めた大腸癌肝転移 症例における DI の変化は +4 点で, 中心壞死を認め なかった NC群の DI の変化より大きく，それは PR 群に近似した。

局所温熱療法併用肝動注が施行された転移性肝癌に おける治療前後の DI の変化を図 3 に示した。局所温 熱併用肝動注症例には PR 群, PD 群はなかった. $\mathrm{NC}$ 群の中で治療後に中心壊死を認めた症例の DI の 変化は+3点で, 中心壊死を認めなかった $\mathrm{NC}$ 群の DI の変化 $(0$ 点〜 +2 点) より大きかった.

PR 群

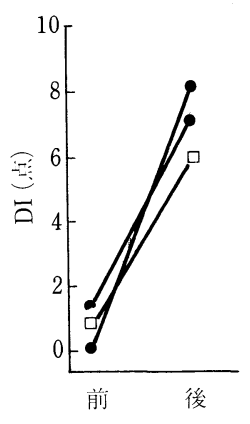

\section{3. 治療前後における DI の変化と治療後生存期間}

図 4 に大腸癌肝転移症例（n=10）における治療前 後の DI の変化と治療後生存曲線を示した. 両者間に は有意な $(\mathrm{P}<0.001)$ 相関関係を認め, DI の変化が 大きい症例活ど治療後生存期間が長かった。

\section{IV. 考察}

日癌治判定基準 ${ }^{1)}$ の問題点の 1 つに, 組織学的判定 基準が示されていないということがあげられる。ま た, 組織学的判定基準が癌取り扱い規約に明示されて いる胃癌(6)や大腸癌7に抢いても組織学的判定基準と 奏効度との関係は明確ではない. 今回われわれは, 体 表病巣のみならず，体深部病巣である転移性肝癌から

$\longrightarrow$ 転移性肝音 (原発巣：大腸岟) (中心壊死 + )

NC 群 (中心壊死一)

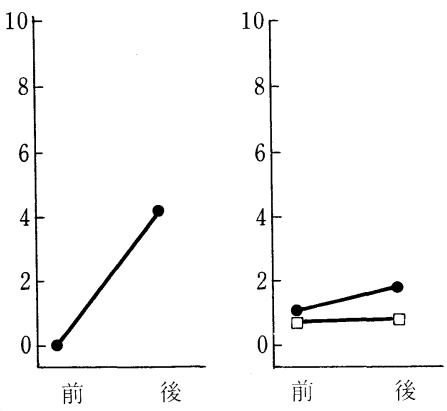

$\mathrm{PD}$ 群

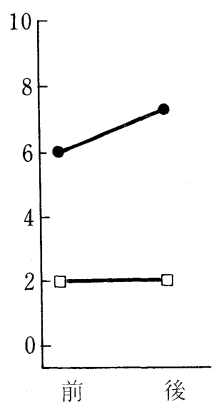

図 2 肝動注が施行された転移性肝癌における治療前後の DI の変化
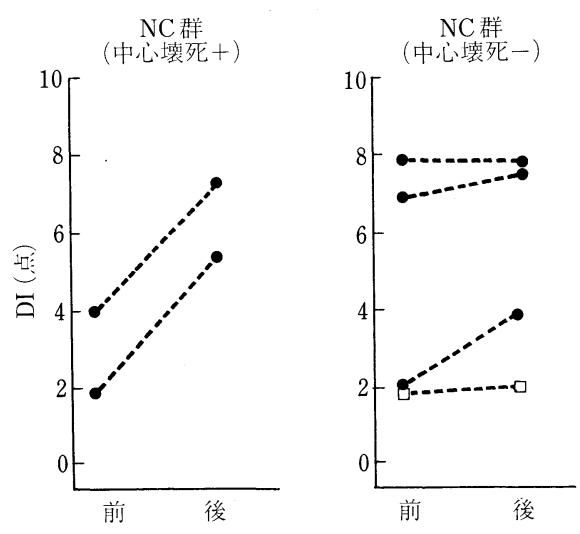

転移性肝癌 (原発巣：大腸癌)

…… 転移性肝癌(原発巣：胃癌)

図 3 局所温熱療法併用肝動注が施行された転移性肝癌にお ける治療前後の DI の変化

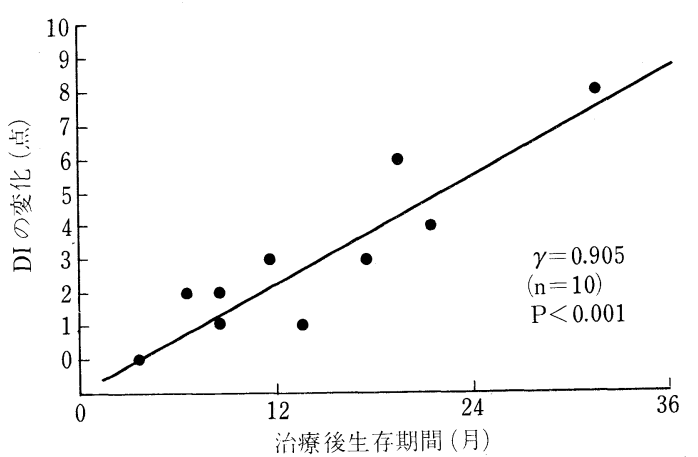

図 4 転移性肝癌（大腸癌原発）の治療前後におけるDIの 変化と治療後生存期間 
も, 容易にかつ安全に腫瘍の辺縁から中心部まで細胞 採取が可能である ${ }^{8)}$ 穿刺吸引細胞診の手技を用いて, 治療前後における癌細胞の変性度 (DI) と奏効度と の関係を検討した。 その結果, 体表病巣の乳癌ならび に体深部病巣の転移性肝癌において, DI の変化と奏 効度とはよく一致した。さらに，CTのみでは判定が 不十分であった転移性肝癌における中心壊死症例にお いても, 局所治療効果の判定は可能であったことよ り, 本法は組織学的判定基準にかわりうる治療効果判 定法として，臨床に応用できるのではないかと思われ た。

細胞診を用いた癌治療効果判定法としては柴田ら ${ }^{9)}$

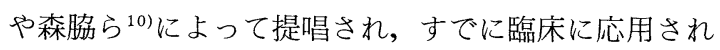
ているものもあるが, それらは放射線照射による細胞 学的治療効果判定基準であり, 化学療法における細胞 変化は放射線療法に比べて種々の変性段階の細胞が混 在し, 癌細胞陰性化に至るまでの経過が長く, 効果の ばらつきが大きく ${ }^{11)}$ かつ複雑であるため ${ }^{12)}$, 前述の基 準は化学療法による細胞学的効果判定法として活用さ れていないのが現状である11). それに対してわれわれ の試みた方法は, 化学療法を施行した乳癌および転移 性肝癌の局所治療効果判定法として有用であることが 示唆されたことより, 癌化学療法後の細胞学的効果判 定基準としての活用が期待できるのではないかと思わ れた。

治療効果を論ずるうえで重要なことの 1 つに, 治療 によって得られた効果が生存期間の延長に結び付くの が本来の姿ではないか, という考えがある、しかる に, 癌患者の生存期間は治療のみならずその他種々の 要因によって影響を受けるため4), 奏効度と延命とは 必ずしも一致しない尚のが現状である。もし，局所治 療効果の判定がそのまま予後予測因子となりうるなら ば, 治療効果判定法として非常に有用であることは間 違いないであろう。細胞像の変化と予後との関係を論

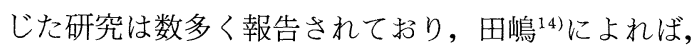
子宮頸癌患者の治療前の癌細胞の形態から 70〜80\% の高頻度で予後が推定できたとしている。また， Graham $^{15)}$ も放射線照射による良性細胞の変化は予後 推定の参考になると報告している，今回，われわれが 試みた治療前後におけるDIの変化は点数となって表 され, その点数が大きい大腸癌肝転移症例では予後も 良好であった。

以上より，穿刺吸引細胞診を用いた本法は新たな治 療効果判定法の 1 つになりうるものと考えられるが,
一方で本法の問題点も指摘されている. それは, 体深 部病巣では治療前後における同一部位からの確実な細 胞採取は困難ではないかということである。 その問題 点に対してわれわれは, 可能なかぎり腹部超音波画像 上同一部位を確認し，比較的壊死の少ない腫瘍の辺縁 を中心に細胞を採取することで克服できると考えてい る.

\section{Summary}

We evaluated the effects of chemotherapy for breast cancer and metastatic liver cancer using aspiration biopsy cytology.

In 3 patients with breast cancer and 14 patients with liver metastases (10 from colorectal cancer and 4 from gastric cancer), cancer cells were obtained by the aspiration technique before and after treatment with intra-arterial infusion chemotherapy combined with local hyperthermotherapy. The degeneration indices (DI) of cancer cells were scored with predetermined criteria before and after treatment, and the correlation between changes in DI and the clinical response rate to treatment was investigated.

The morphological changes in cancer cells consisted mainly of nuclear changes such as enlarged or swollen nuclei, giant cell formation with multiple nuclei and rough nuclear chromatin. The change in DI showed a good correlation with the rate of clinical responsiveness to treatment, and all of the patients with a DI difference exceeding 5 points between pre- $^{-}$and post-treatment showed a partial response to chemotherapy. There was a significant correlation between the DI difference and the survival period in patients with liver metastases from colorectal cancer $(\mathrm{P}<0.001)$.

These results suggest that the DI change in cancer cells obtained by aspiration biopsy cytology is a useful means of evaluating chemotherapeutic effects at the local level and may serve as a prognostic parameter in patients with liver metastases from colorectal cancer.

\section{文献}

1）日本癌治療学会. 固形がん化学療法直接効果判定基準. 日癌治療会誌 $1986 ； 21 ： 931 \sim 941$.

2) WHO. WHO handbook for reporting results of cancer treatment. WHO offset publication No. 48. Geneva: WHO, 1979.

3) Moertel, C.G., Hanley, J.A. The effect of measuring error on the results of therapeutic trials in advanced 
cancer. Cancer 1976；38：388〜394.

4) 賀古 真. 癌化学療法の問題点・肝臟. 癌と化療 1989 ; $16: 307 \sim 310$.

5) 古江 尚. 癌化学療法効果判定の問題点. 癌と化療 $1989 ; 16: 297 \sim 301$.

6）胃癌研究会編. 胃癌取り扱い規約. 第 12 版. 東京：金 原出版, $1993 ; 136$.

7）大腸癌研究会編. 大腸癌取り扱い規約. 第 5 版. 東京： 金原出版, 1994：42.

8) Hirooka, Y., Matsui, T., Kobayashi, Y., Kimura, A., Iitsuka, Y. Evaluation of aspiration biopsy cytology in disease of the liver, gallbladder and pancreas. Yonago Acta Med. 1987 ; 30 (suppl) : 95 104.

9）柴田偉雄，坪井栄孝，尾形利郎，鈴木 明. 経時的細胞 診による肺癌の放射線療法および化学療法の効果判定に
ついて. 癌の臨 $1968 ; 14: 310 〜 323$.

10）森脇昭介, 猪原照夫, 吉田岑雄. 子宮頸癌放射線治療効 果の記号化. 癌の臨 $1971 ； 17 ： 704 \sim 706$.

11）柴田偉雄. 子宮頸癌の治療と細胞診. 癌と化療 1982 ; $9: 1704 \sim 1710$.

12）松田 実, 宝来 威. 肺癌の治療と細胞診. 癌と化療 $1982 ； 9:$ 1695 1703.

13） 中尾 功. 消化器癌化学療法の効果判定基準の問題点に ついて. 癌と化療 $1989 ; 16: 302 〜 306$.

14）田嶋基男. 癌の治療と細胞診. 癌と化療 $1982 ; 9: 1688$ $\sim 1694$.

15) Graham, R.M. Effect of radiation on vaginal cells in cervical carcinoma. I description of cellular changes ; II prognostic significance. Surg. Gynec. \& Obst. $1974 ; 84: 153 \sim 166$. 